AT-TAJDID: Jurnal Pendidikan Dan Pemikiran Islam

(p-ISSN: 2548-5784 |e-ISSN: 2549-2101)

Vol. (05) (01), (Januari-Juni) (2021), (28-41)

Doi: http://dx.doi.org/10.24127/att.v5i01.1473

\title{
THE RELEVANCE OF INQUIRY-BASED LEARNING IN BASIC READING SKILLS EXERCISES FOR IMPROVING STUDENT LEARNING OUTCOMES IN MADRASAH IBTIDAIYAH
}

\author{
Prasetyono Hendriarto ${ }^{1}$ \\ Universitas Pakuan, Indonesa ${ }^{1}$ \\ mas.pras@coret.page ${ }^{1}$ \\ Aslan' \\ Institut Agama Islam Sultan Muhammad Syafiuddin Sambas ${ }^{2}$ \\ aslan@iaisambas.ac.id ${ }^{2}$ \\ Mardhiah $^{3}$ \\ UIN Alauddin Makassar, Indonesia ${ }^{3}$ \\ mardhiah.hasan@uin-alauddin.ac.id ${ }^{3}$ \\ Rahmat Sholihin ${ }^{4}$ \\ UIN Antasri Banjarmasin, Indonesia ${ }^{4}$ \\ rahmatsholihin@uin-antasari@ac.id ${ }^{4}$ \\ Suhono 5 \\ Institut Agama Islam Ma'arif NU (IAIMNU) Metro, Indonesia ${ }^{5}$ \\ Suhono120708@gmail.com ${ }^{5}$ \\ Wahyudin ${ }^{6}$ \\ UIN Antasri Banjarmasin, Indonesia ${ }^{6}$ \\ wahyubanjarmasin@gmail.com ${ }^{6}$
}

\begin{abstract}
ABSTRAK
Penelitian ini membahas tentang kegiatan pembelajaran berbasis inkuiri dalam pelatihan keterampilan membaca siswa di Madrasah Ibtidayah dan sekolah dasar di Indonesia. Dalam pembelajaran memahami menurut Islam, keterampilan membaca mendapat perhatian khusus dari keterampilan lain seperti keterampilan berbicara, menyimak, dan menulis. Mendapatkan pemahaman dan penerapan pembelajaran memperkuat membaca yang dapat dimulai dari tingkat sekolah dasar, dan tema ini akan dibahas dengan metode literature review dari publikasi jurnal nasional dan internasional. Studi desain deskriptif kualitatif akan menjadi metode analisis rangkaian data. Proses review melibatkan pendekatan fenomenologis, sistem pengkodean, dan evaluasi kritis untuk menghasilkan temuan data untuk menjawab tema penelitian kami yang memenuhi validitas dan reliabilitas temuan. Akhirnya, dapat disimpulkan temuan kami, antara lain bahwa kesepuluh publikasi dan literatur telah menegaskan bahwa penerapan pendekatan pembelajaran berbasis inkuiri sangat relevan untuk diterapkan di lingkungan pembelajaran sekolah dasar. Dengan demikian temuan ini akan berguna bagi pihak manapun.
\end{abstract}

Kata Kunci: Pembelajaran Inkuiri, Keterampilan Membaca, Siswa Sekolah Madrasah. 


\begin{abstract}
This study discussed inquiry-based learning activities in reading skills training students in Madrasah Ibtidayah and elementary schools in Indonesia. In learning to understand according to Islam, reading skills receive special attention from other skills such as speaking, listening, and writing skills. Get an understanding and application of strengthening reading learning that can be started from the elementary school level, and this theme will be discussed with the literature review method from national and international journal publications. A descriptive qualitative design study will be a method of analyzing a series of data. The review process involves a phenomenological approach, coding systems, and critical evaluation to produce data findings to answer our research themes that meet the findings' validity and reliability. Finally, we can conclude our findings, among others, that the ten publications and literature have confirmed that the application of inquiry-based learning approaches is very relevant to be applied in the learning environment of elementary madrasah schools. Thus these findings will be useful to whichever party.
\end{abstract}

Keywords: Inquiry-Based Learning, Reading Skills Excercise, Madrasah School Students.

\section{A. INTRODUCTION}

When returning to the incident when Prophet Muhammad SAW received a revelation from the Angel Jibril, all Muslims will remember the word 'Iqra' or 'reading' in a foreign language. (Meijer, 2009; Aslan, 2019; Aslan, 2017; Aslan \& Yunaldi, 2018; Aslan, Suhari, et al., 2020; Aslan, Sihaloho, et al., 2020). So there is nothing wrong with Muslims being inspired by this incident so that all learning activities are related to reading skills. The reading activity is one of the four skills in learning the language that requires special attention (Suhono, 2019). Reading is a process carried out and used by readers to get messages, which the writer wants to convey through the media of written words/languages. Reading is one aspect of language skills that contain meanings that are not always the same for everyone; some view reading as a passive process, and some say that reading is an active cognitive process (Anwar, 2020). However, reading is the ability to pronounce the sound symbols of a language and understand their meaning (Suhono \& Sari,
2020). Based on the importance of reading, teachers and parents should understand ways that can be used in order to make reading activities a success. One of the methods or approaches teachers can take on teachers is the Inquiry-based reading practice approach. (Shih et al., 2010; Rachmawati et al., 2020; Aslan, Silvia, et al., 2020).

Before we take our readers further, it is better if we first state what we mean by system learning or the inquiry-based approach in reading skills training among children's learning at the school level at Madrasah Ibtidaiyah, which is the primary school in the Islamic education curriculum. The term inquiry-based learning is a learning approach that focuses on optimizing children's abilities in following the teaching and learning process in schools. (Laksana, 2017; Spronken-Smith \& Walker, 2010). The method is straightforward, starting from the teacher's role in telling students how and what students must understand. In other words, students are motivated to research reading material by multiplying questions as a feeling of curiosity so that the children have thoughts 
and ideas before the core of the reading lesson begins.

Furthermore, teaching students' reading is inquiry-based, namely learning using learning methods that teachers often do in class, such as collaborative discussions, and a learning system that combines learning and research focused on student activities. The point is that the teachers do not take the teaching and learning method of memorizing facts and history. (Friesen \& Scott, 2013; Putra \& Aslan, 2019). Students learn with inquiry-based methods quickly done by doing more work and like playing and learning a little. This inquiry method allows students to construct knowledge and experiences on learning content through exploration, research, observing, and talking.

Practicing reading with an inquirybased activity approach is essentially something that is not too difficult that frightens students. Because this activity does not involve reciting facts and formulas, but it does involve seeing, digesting, doing, and thinking more critically. As a process of seeing reading with the inquiry method, understanding the symbols of written letters into spoken words is a process of understanding the symbols of written letters. Likewise, the critical thinking process, reading activities involve symbol recognition, literacy interpretation, understanding, critical analysis, and creativity skills (Umar, et al., 2020). Khalaf, (2018) defines the Inquiry-Based Learning method as a method in education that emphasizes students' pedagogical aspects, not teaching the concept of one-way communication. Meanwhile, Riyanti et al.,
(2016) said implementation teaching reading for students in college. They understand reading activities to be an effort to understand the meaning in the written context by understanding symbols and processing literacy, written language.

Like teaching other content, teaching reading skills certainly requires an appropriate and practical approach based on recommendations from experts in teaching reading. Chu et al., (2021) advised that in the 21 st-century skills development through inquiry-based learning from theory to practice from various contexts and content. We can share the methods and stages in teaching reading skills, for example, the steps and stages of teaching, namely the Inquiry-Based Learning method. In the first stage, as directed by Shih et al., (2010) in their study "An inquiry-based mobile learning approach to enhancing social science learning effectiveness," students are allowed to develop questions that later require appropriate answers.

In essence, the inquiry approach method allows students to be able to ask questions and answer freely. Another approach, for example, students, are allowed to examine the teacher's themes in class. So this inquiry approach also prioritizes students to familiarize themselves with their research talents and find out something that is a problem to find answers or solutions. Another approach can be that students are allowed to share a lot and help friends with the experiences they have gone through so that it is easy to convey. In other words, this method accustoms students to communicate well and on target academically and intellectually. Ask students to think 
reflective thoughts about what could make the process possible and what could not happen.

According to Kaiser et al., (2018) another benefit of applying the inquirybased learning method in reading class for children is that teachers can foster students' curiosity indefinitely until they get what they are looking for. Because an inquirybased approach promotes students, share experiences and ideas through the freedom to ask fellow students and even with the teaching council. This method is beneficial for students' mental and cognitive development with curiosity about what the teacher assigns. This method also teaches skills that students can apply to continue exploring all happy issues.

Likewise, Brookhart et al., (2009) the inquiry-based learning method will promote student ownership of learning through highimpact student involvement in both learning sessions and evaluating practices. Furthermore, this method allows students to feel the learning ownership of classroom learning. Also, students have time to explore a topic, giving students a greater sense of responsibility for the lesson's actions. Instead of the teachers themselves who have to be active in conveying what they have to learn, with the inquiry method, students can be more active in a way that is suitable for students' preferences and in the way they are most happy to learn; not otherwise students must learn by being forced by the teacher.

Besides, said Gambrell, (2011) there are seven ways of student engagement in subject topics. According to him, there is the most important thing, for example, the teacher must know about motivation to read. So through an inquiry approach, students have the opportunity to dive into the reading material they have to learn thoroughly. Because inquiry-based learning will form active learning, this approach is proven to attract students to be fully active with the theme of reading learning. By giving students active opportunities to explore topics, this method makes connections on their own, and by asking questions and answers, they can learn more effectively and proactively.

According to Gregory \& Kaufeldt, (2015) what is even more beneficial is that the inquiry-based learning approach can motivate student's brain while increasing the attention, engagement, and perseverance of students. These are all methods that will increase students' love for learning, not the other way around teachers who have to tell students to be happy with their lessons wearily. Finally, the inquiry method is designed to promote students' love for their lessons. So when students can jump right into reading topics in their autonomous way, students not only gain a more harrowing experience - students will also sharpen their desire to explore the subjects and themes they like.

\section{Improving Children's Reading Skill}

Küçükoğlu, (2013) states that improving reading skills among students can be done by choosing strategic learning. So the solution is that teachers and researchers are needed to intervene to improve students' skills in the classroom.

Abd Kadir et al., (2014) 's advice states the importance of teaching critical reading methods in reading classrooms. Based on 
experts' opinions, one of the appropriate methods is the inquiry-based approach, which is a relevant solution. To teach reading skills to become real, teachers also need an effective teaching methodology by combining various methods. So whatever material resources and methods are used, the final goal is to improve student learning, especially reading, which must be a priority with the maintained quality so that the ability and opportunity to be able to read, which is the main goal, is essential to help children become skilled at reading. Bringing all of these aspects into existence requires cooperation on studies, schools, parents of students, and the wider community.

To get there, efforts to strengthen the research and development agency's student education functions also need special attention. Because through the findings of their studies, researchers will produce new methods of accelerating elementary and middle school students' learning outcomes. According to the study of Oakhill et al., (2014) understanding and teaching reading comprehension requires serious handling. They say skills that are very important in academic and real-life settings include reading skills because they do not just grow. These skills must be taught and trained from the start of school. (Monaco \& Martin, 2007; Putra \& Aslan, 2020; Putra et al., 2020). Therefore, all parties in education must understand that reading skills are special skills because reading skills are the key to children's success in learning. The better the children's reading skills, the better their learning achievement. Palmer, (2014) also supports children's learning as early as possible so that one day it will become a generation of millennials who have improving self-efficacy in kids learning time.

Furthermore, efforts to improve primary madrasah students' reading skills are a problem in education services in the country. The 2016 national elementary school student skill test at the government's initiation shows that students' reading ability is still deficient; namely, elementary school students are still at $46.83 \%$ who are not skilled in reading skills. Elementary schoolage reading skills are a gateway to learning and the development of life skills for the future of advanced Indonesian youth.

Goodman et al., (2015) boldly say that the challenge for American children's skills lies in millennials' skills and the future they are prepared for. So they believe American children's education services are in the transfer of high academic skills, especially reading skills. It does not matter if we believe that only with skilled reading, the nation's children will be able to learn all subjects and the complexities of a challenging future. Through reading skills, children can understand, analyze, and apply the reading content they read and can develop reading content into new understandings.

Because reading skills are so heavy, Welsh et al., (2010) agree that developing cognitive skills through reading is an effort to increase children's readiness to enter the next school level. A solution that can be applied to improve students' literacy skills is reading skills at the child's elementary school age or early years. Researchers and developers of the reading curriculum for elementary school students should become 
active and essential partnerships with teachers with various innovative programs to improve reading and numeracy literacy learning outcomes for elementary and madrasah students. (Aslan, 2019; Aslan, 2018; Aslan \& Suhari, 2018).

Finally, we believe that the primary quality of education for school children is based on reading skills. This is very important for all Indonesian education leaders because serving education must directly contribute to children's development from elementary schools, and academic staff must be equipped with quality and production facilities and concepts and teaching methods. We are very proud to provide support by studying teaching innovation studies, such as the study of the understanding of the inquiry-based teaching approach. The reading skills of madrasah and elementary school students, which are the origin of life, changes for every human child, one of which is through improving pulmonary teaching methods, especially reading skills. (Gao et al., 2019).

Especially if it is connected with strategies and planning for literacy programs for elementary school-age children, reading skills significantly contribute to improving the critical thinking skills required at each final level with high-level students' thinking skills, namely higher-order thinking skills. So finally we need changes in methods and methods as well as policies to help teachers and other educational components to be able to change the old learning process towards new ways of strengthening the acceleration of achieving the two goals of literacy in Indonesia (Kristiawan, et al., 2021), increasing a more competitive reading level, and developing all the potential of primary school children through the development of national and spiritual character in the school and community environment.

\section{B. METHODOLOGY}

Our review aims to understand the relevance of inquiry-based learning as a reading skills training needed to improve student learning outcomes at Madrasah Ibtidaiyah in Indonesia. The achievement of student learning outcomes in primary schools or madrasah ibtidaiyah is still a heated debate among educators and others outside the education system. However, we believe that the learning in question is closely related to selecting learning methods and approaches applied in the classroom. One of the relevant approaches studied is inquiry-based learning in improving the reading skills needed by students. To that end, we have obtained data from various educational contexts that have successfully linked their inquiry-based learning. After studying it under the phenomenological approach and critical analysis by linking the study theme with field data, the data we presented was valid and reliable. Finally, we get results, among others, as reported in the Results section of this paper. This qualitative study report is supported by the study design conducted by Ezzy, (2013) in his work "qualitative analysis' and Zhang \& Wildemuth, (2009) through his paper" Qualitative analysis of content."

\section{RESULT AND DISCUSSION}

Inquiry-based applicable in multiple learning contexts 
As an educational expert, finding from Nunaki et al., (2019) can help request a learning inquiry approach. It is a realization that may prepare understudies' metacognitive abilities. In this investigation, 70 understudies were given request based learnings in Indonesia. It was discovered that the inquiry-based method was discovered to be powerful. There was no critical contrast between male understudies 'and female understudies' abilities. Further investigations may inspect the distinction of male and female understudies' meet intellectual abilities dependent on evaluation, age, or character of participants.

If we to seek the relevancy of inquirybased approach into teaching young learners to readability, the study from Thaiposri \& Wannapiroon, (2015) has proven that their examination depicts the learning exercises and surveys fittingness utilizing an assessment structure. The examination test was purposively chosen and comprised of ten specialists in advanced education instructional plan, request based learning movement plan, informal organizations, distributed computing, and improving necessary reasoning abilities. The example decided on the learning Activities as profoundly proper and pertinent to actual practice. The examination discoveries were as per the following. They are learning exercises comprised of three main steps; 1) pre-educating and learning readiness, 2) improving understudies' necessary reasoning abilities through instructing and acquiring by request based learning. exercises utilizing informal community and distributed computing, and; 3) estimation and assessment.
The following result from Abdi, (2014) who investigate the effects of inquiry-based learning method on students' academic achievement in sciences lesson have motivated students behind this examination was to explore the impacts of request put together learning technique concerning understudies' scholastic accomplishment. A sum of 405 th grade understudies from two distinct classes was associated with the investigation. The outcomes demonstrated that understudies who were told through request based learning were accomplished higher score than those guided through the conventional technique. This exploratory investigation endured two months.

Magee \& Flessner, (2012) collaborated to improve inquiry-based teaching in elementary science and mathematics methods courses and examine the impact of advancing demand-based education through collaboration between science strategy courses and mathematics engineering courses. Preservice Basic Instructor (PST) applicants experience three unique requests to develop a broader understanding of demand-based education (IBT). The meeting combined PST-based science requests and arithmetic requests where the PST were students and science requests where they became educators.

Ramnarain \& Hlatswayo, (2018) have tested the teacher believes in teaching, and demand-based learning continues to be a test for several South African instructors. Educators ensure that the implementation of demand-based learning is fraught with problems. The absence of a research headquarters, materials on display, time to complete educational plans, and large 
classes made it difficult to implement. The exam was led by distributing an approved survey to Physical Science educators in Mpumalanga, South Africa. It is well known that tested educators have an inspirational mentality to the demands of teaching Physics but are less inclined to order demand in their practice.

Panasan \& Nuangchalerm, (2010) studied the learning outcomes of projectbased and inquiry-based learning activities with the association of effort-based and demand-based learning exercises, suggesting strategies that can help students understand logical information. This investigation is intended to analyze learning achievement, measure the ability of science and logic to remember grade 5 students who learn to use these strategies. Comprehension in the two meetings did not indicate different learning achievement and sci-tech abilities. According to the test results, plans for business associations and demand in science learning exercises are excellent and exciting. The plan has an efficiency of $89.05 / 78.79$. project-based learning and 87.58 / 80.64 of request Based Learning. This article was initially distributed as a feature of the June 2008 Daily Mail Online printout.

Van Allen \& Zygouris-Coe, (2019) reviewed the use of guided reading to teach internet inquiry-based skills: a case study of one elementary school teacher's experience. Those understudies battle online exams and comprehension skills, leaving them unprepared for school and the profession. This investigation illustrates how grade 4 instructors built their students' online exploration skills. Teachers adopt a large number of guided reading systems to create on-demand online capabilities. Both educators and students experienced job changes and provocations identified by experience, but students demonstrated a high speed of commitment and coordinated effort.

Voet \& De Wever, (2016) examined the history of teachers' concepts of inquirybased learning, beliefs about the nature of history, and their relations to the classroom context. Their current investigation provides a complete picture of the origins of demandbased learning (IBL) of history educators, concerning meetings with 22 optional teachers. The results show that, although most instructors' beliefs about historical ideas are helpful for training recorded thinking, the origins of their IBL often remain limited to a fundamental assessment of data, rather than using accessible data to lead investigations into the past. Besides, the IBL educators' origin has all the characteristics associated with their work environment. Based on these findings, several consequences for supporting historical instructor acceptance of IBL are discussed.

Pedaste et al., (2015) have identified a relationship between students' level of reflection and their inquiry learning outcomes after completing a complete inquiry cycle in the online Go-Lab Inquiry Learning Space (ILS). According to them, demand-based learning is gaining a foundation in science education planning, innovative work, and teaching. Articles centered around identifying and summarizing the main highlights of demand-based learning. It builds a mixed demand cycle that incorporates the quality 
of existing demand-based learning systems. This article concludes with the Conclusion stage, which can be present at any time during Demand-based learning. The Discussion Stages (which combine Communication and Reflection) can also be linked to the various stages, as they can occur at any time during (a conversation in real life) or after (talking about an activity), as in thinking, come back before or later. It ends with a structure describing the demand cycle in which these stages and sub-stages will be available in learning interaction. The system starts with an Orientation and coursework through Conceptualization.

Khalaf, (2018) reviews the pedagogy of traditional and inquiry-based learning through a systematic critical review. He saw that the traditional learning model was a technique that was already applicable in the field of learning. Demand-based learning has been widely stated to broaden the information and abilities of students. A hole was found between current learning techniques and the assumptions for our instructive framework. Another educational plan is essential to emphasize favorable circumstances and discredit both learning models' inconveniences, the investigation said. The inquiry relies on 43 observational investigations announced in writing somewhere between 2002 and 2017. It identifies significant losses to both adat and demand.

\section{DISCUSSION}

An understanding of the application of the teaching method approach for educators is critical. It is evident from the findings of research that examines the relevance of inquiry-based learning approaches to the bare reading of essential reading among madrasah ibtidaiyah students in Indonesia, which will be very useful, especially for madrasah or elementary school educators who have a big responsibility for learning success of essential reading skills education. By considering various literature and reviews of publications from various educational contexts, it can finally be said that inquirybased methods or approaches are very relevant in the context of basic reading classes in madrasah intidaiyah, the primary education environment. With the evidence from the field evidence that we examined, we can understand that the inquiry-based best practice method amazes students because this learning model is very different from the conventional learning system in schools. The madrasah learning method is still the central teacher orientation method. A similar point has been discussed by

Schalk et al., (2019) who examined efforts to increase the implementation of variable-control strategies as a guarantee of the benefits of inquiry-based physics education in primary schools. So if we examine its relation to reading skills, Schalk does it by linking it to physics education. The point is that there are similarities in benefits even though the context is different.

Of the ten publications we visited, they have confirmed several advantages to the inquiry method they have studied in various education and study units. However, we can briefly say that 1) inquiry-based learning strategy that positions activities and learning objectives for the development and training of cognitive, affective, and psychomotor 
progress systematically. So as a teacher must understand the advantages of this inquiry-based method; learning in the field can be carried out through this strategy more meaningfully. 2) This best practical inquiry application will promote students to learn and play in the typical age and learning styles of first to sixth-year madrasa school students. For the advantages of this inquiry system, it has proven to be the choice of many educators and researchers of primary school age learning outside the country. For example, a study by Laursen et al., (2014) successfully found out the advantages of this method in their study "Benefits for women and men of inquiry-based learning in mathematics college: A multi-institution study."

For this reason, studies that understand the effectiveness of inquiry-based learning in learning models in the advanced era with attractive, innovative methods will help educators achieve student learning goals, especially at the elementary madrasah level. It must be admitted that the adoption of an inquiry-based approach is challenging because not all teaching practices will produce the same impact even though they have used the same methods. This is what will foster the spirit of educators in helping students to be able to acquire the skills students need in mastering educational material. Applying inquiry-based learning to achieve reading learning outcomes at the madrasah level requires strategic strategies that are following the conditions and potential of students because the compatibility between the choice of method and the objectives to be achieved will actively make it easier for teachers and students to solve problems, such as collaboration methods, and increase skills. Essential reading that prepares students to continue learning to the next level well. (Harahap, 2019). In his study understands the effect of the Inquiry-Based Learning application on students' abilities in writing skills.

\section{CONCLUSION}

Finally, we can conclude that the review study, to understand the relevance of inquiry-based learning applications in teaching reading skills in elementary schools and madrasah ibtidaiyah in Indonesia, has brought results. The ten papers published in several different journals have indicated that this inquiry-based learning approach is very suitable for learning necessary reading skills at the elementary school or elementary madrasah level. This approach gets the right place in many contexts and levels of education is none other than the strategies and methods that the inquiry application has is very helpful for students and students in achieving the ultimate goal of improving student learning outcomes. So we suggest all researchers and educators evaluate the results of this study so that one day it will be useful to find a reading learning solution for Indonesian children.

\section{E. REFERENCE}

Abd Kadir, N., Subki, R., Jamal, F. H. A., \& Ismail, J. (2014). The importance of teaching critical reading skills in a Malaysian reading classroom. International Academic Conference, 208-218. 
Abdi, A. (2014). The Effect of InquiryBased Learning Method on Students' Academic Achievement in Science Course. Universal Journal of Educational Research, 2(1), 37-41.

Anwar, A. K. (2020). The Effect of Collaborative Strategic Reading Toward Students Reading Skill. Anglophile Journal, 1(1), 21-28.

Aslan. (2018). Dinamika Pendidikan Islam di Zaman Penjajahan Belanda. SYAMIL: Jurnal Pendidikan Agama Islam (Journal of Islamic Education), $\quad 6(1), \quad 39-50$. https://doi.org/10.21093/sy.v6i1.102 4

Aslan. (2019). Hidden Curriculum. Pena Indis.

Aslan. (2019, January 17). Pergeseran Nilai Di Masyarakat Perbatasan (Studi tentang Pendidikan dan Perubahan Sosial di Desa Temajuk Kalimantan Barat) [Disertasi dipublikasikan]. Pasca Sarjana. https://idr.uinantasari.ac.id/10997/

Aslan, A. (2017). Nilai-nilai kearifan lokal dalam budaya pantang larang suku melayu sambas. Jurnal Ilmiah Ilmu Ushuluddin, 16(1), 11-20. http://dx.doi.org/10.18592/jiu.v16i1. 1438

Aslan, A., Silvia, S., Nugroho, B. S., Ramli, M., \& Rusiadi, R. (2020). TEACHER'S LEADERSHIP TEACHING STRATEGY SUPPORTING STUDENT LEARNING DURING THE COVID-19 DISRUPTION. Nidhomul Haq: Jurnal Manajemen Pendidikan Islam, 5(3), 321-333. https://doi.org/10.31538/ndh.v5i3.98 4

Aslan, Sihaloho, N. T. P., Nugraha, I. H., Karyanto, B., \& Zakaria, Z. (2020). Paradigma Baru Tradisi "Antar Ajung" Pada Masyarakat Paloh,
Kabupaten Sambas. IBDA`: Jurnal Kajian Islam Dan Budaya, 18(1), 87-103.

https://doi.org/10.24090/ibda.v18i1.3 354

Aslan \& Suhari. (2018). Pembelajaran Sejarah Kebudayaan Islam. Razka Pustaka.

Aslan, Suhari, Antoni, Mauludin, M. A., \& Mr, G. N. K. (2020). Dinamika Keagamaan Masyarakat Perbatasan Paloh Kabupaten Sambas, Kalimantan Barat. Jurnal Antropologi: Isu-Isu Sosial Budaya, 22(1), 90-101. https://doi.org/10.25077/jantro.v22.n 1.p90-101.2020

Aslan, \& Yunaldi, A. (2018). Budaya berbalas pantun sebagai media penyampaian pesan perkawinan dalam acara adat istiadat perkawinan melayu sambas. jurnal transformatif (ISLAMIC STUDIES), 2(2), 111122. https://doi.org/10.23971/tf.v2i2.962

Brookhart, S., Moss, C., \& Long, B. (2009). Promoting student ownership of learning through high-impact formative assessment practices. Journal of MultiDisciplinary Evaluation, 6(12), 52-67.

Chu, S. K. W., Reynolds, R. B., Tavares, N. J., Notari, M., \& Lee, C. W. Y. (2021). 21st century skills development through inquiry-based learning from theory to practice. Springer.

Ezzy, D. (2013). Qualitative analysis. Routledge.

Friesen, S., \& Scott, D. (2013). Inquirybased learning: A review of the research literature. Alberta Ministry of Education, 32.

Gambrell, L. B. (2011). Seven rules of engagement: What's most important to know about motivation to read. 
The Reading Teacher, 65(3), 172178.

Gao, Q., Wang, H., Rozelle, S., Shi, Y., Li, J., Zhang, L., \& Nie, W. (2019). School-based reading interventions for improving reading skills and educational outcomes on primary school students in low-and middleincome countries: A systematic.

Goodman, A., Joshi, H., Nasim, B., \& Tyler, C. (2015). Social and emotional skills in childhood and their longterm effects on adult life. London: Institute of Education.

Gregory, G., \& Kaufeldt, M. (2015). The motivated brain: Improving student attention, engagement, and perseverance. ASCD.

Harahap, N. C. (2019). The Effect Of Applying Inquiry Based Learning (IBL) on Students' Ability In Persuasive Writing [PhD Thesis]. Universitas Muhammadiyah Sumatera Utara.

Kaiser, I., Mayer, J., \& Malai, D. (2018). Self-generation in the context of inquiry-based learning. Frontiers in Psychology, 9, 2440.

Khalaf, B. K. (2018). Traditional and Inquiry-Based Learning Pedagogy: A Systematic Critical Review. International Journal of Instruction, 11(4), 545-564.

Küçükoğlu, H. (2013). Improving reading skills through effective reading strategies. Procedia-Social and Behavioral Sciences, 70, 709-714.

Kristiawan, M., Suhono, S., Yussof, M. H. B., \& Muslimah, M. (2021). The International School's Culture in Indonesia and Brunei Darussalam. Jurnal Iqra': Kajian Ilmu Pendidikan, 6(1), 180-191.

Laksana, D. N. L. (2017). The effectiveness of inquiry based learning for natural science learning in elementary school. Journal of Education Technology, 1(1), 1-5.

Laursen, S. L., Hassi, M.-L., Kogan, M., \& Weston, T. J. (2014). Benefits for women and men of inquiry-based learning in college mathematics: A multi-institution study. Journal for Research in Mathematics Education, 45(4), 406-418.

Magee, P. A., \& Flessner, R. (2012). Collaborating to improve inquirybased teaching in elementary science and mathematics methods courses. Science Education International, 23(4), 353.

Meijer, W. A. J. (2009). Tradition and Future of Islamic Education. Waxmann Verlag.

Monaco, M., \& Martin, M. (2007). The millennial student: A new generation of learners. Athletic Training Education Journal, 2(2), 42-46.

Nunaki, J., Damopolli, I., Kandowangko, N., \& Nusantri, E. (2019). The effectiveness of inquiry-based learning to train the students' metacognitive skills based on gender differences.

Oakhill, J., Cain, K., \& Elbro, C. (2014). Understanding and teaching reading comprehension: A handbook. Routledge.

Palmer, J. S. (2014). The Millennials Are Coming: Improving Self-Efficacy in Law Students through Universal Design in Learning. Clev. St. L. Rev., 63, 675.

Panasan, M., \& Nuangchalerm, P. (2010). Learning outcomes of project-based and inquiry-based learning activities. Online Submission, 6(2), 252-255.

Passey, D. (2013). Inclusive technology enhanced learning: Overcoming cognitive, physical, emotional, and geographic challenges. Routledge. 
Pedaste, M., Mäeots, M., Siiman, L. A., De Jong, T., Van Riesen, S. A., Kamp, E. T., Manoli, C. C., Zacharia, Z. C., \& Tsourlidaki, E. (2015). Phases of inquiry-based learning: Definitions and the inquiry cycle. Educational Research Review, 14, 47-61.

Putra, P. \& Aslan. (2020). Pengembangan bahan ajar berbasis imtaq dan iptek di era revolusi industri 4.0 pada mata pelajaran sains madrasah ibtidaiyah. Ta'Limuna: Jurnal Pendidikan Islam, 9(1), 1-15. https://doi.org/10.32478/talimuna.v9i 1.345

Putra, P., \& Aslan, A. (2019). Exercising Local-Wisdom-based Character Education in Madrasah: An Ethnographic Study in a Madrasah in Sambas, West Kalimantan. Jurnal Pendidikan Agama Islam (Journal of Islamic Education Studies), 7(2), 167-183.

https://doi.org/10.15642/jpai.2019.7. 2.167-183

Putra, P., Mizani, H., Basir, A., Muflihin, A., \& Aslan, A. (2020). The Relevancy on Education Release Revolution 4.0 in Islamic Basic Education Perspective in Indonesia (An Analysis Study of Paulo Freire's Thought). Test Engineering \& Management, 83, 10256-10263.

Rachmawati, M., Widjajanti, S., Ahmad, A., \& Aslan, A. (2020). The English Camps as Method of Promoting Fun English at Elementary School Level in Indonesia. Tapis: Jurnal Penelitian Ilmiah, 4(2), 174-182. https://doi.org/10.32332/tapis.v4i2.2 563

Ramnarain, U., \& Hlatswayo, M. (2018). Teacher beliefs and attitudes about inquiry-based learning in a rural school district in South Africa. South African Journal of Education, 38(1).
Riyanti, A. W., Fauziati, E., \& Fatimah, S. (2016). The Implementation Of Teaching Writing At English Department of Muhammadiyah University of Surakarta In 2015/2016 Academic Year [PhD Thesis]. Universitas Muhammadiyah Surakarta.

Schalk, L., Edelsbrunner, P. A., Deiglmayr, A., Schumacher, R., \& Stern, E. (2019). Improved application of the control-of-variables strategy as a collateral benefit of inquiry-based physics education in elementary school. Learning and Instruction, 59, 34-45.

Shih, J.-L., Chuang, C.-W., \& Hwang, G.-J. (2010). An inquiry-based mobile learning approach to enhancing social science learning effectiveness. Journal of Educational Technology \& Society, 13(4), 50-62.

Spronken-Smith, R., \& Walker, R. (2010). Can inquiry-based learning strengthen the links between teaching and disciplinary research? Studies in Higher Education, 35(6), 723-740.

Suhono, S. (2019). Providing explicit strategy instruction to enhance students'reading comprehension at english for islamic studies class. JURNAL SMART, 5(2), 81-93.

Suhono, S., \& Sari, D. A. (2020).

Developing

Students' Worksheet Based Educational Comic for Eleventh Grade of Vocational High School Agriculture. Anglophile Journal, 1(1), 29-40.

Thaiposri, P., \& Wannapiroon, P. (2015). Enhancing students' critical thinking skills through teaching and learning by inquiry-based learning activities using social network and cloud computing. Procedia-Social and Behavioral Sciences, 174, 2137-

Copyright (C) 2020, Universitas Muhammadiyah Metro| 40 
2144.1

Copyright (C) 2020, Universitas Muhammadiyah Metro| 41 
Umar Al Faruq, A. H., Sari, Y. A., \& Puspita, N. (2020). Applying of Cooperative Integrated Reading and Composition (CIRC) Strategy on Students' Reading Comprehension. Anglophile Journal, 1(1), 41-47.

Van Allen, J., \& Zygouris-Coe, V. (2019). Using guided reading to teach internet inquiry skills: A case study of one elementary school teacher's experience. Reading Psychology, 40(5), 425-464.

Voet, M., \& De Wever, B. (2016). History teachers' conceptions of inquirybased learning, beliefs about the nature of history, and their relation to the classroom context. Teaching and Teacher Education, 55, 57-67.

Welsh, J. A., Nix, R. L., Blair, C., Bierman, K. L., \& Nelson, K. E. (2010). The development of cognitive skills and gains in academic school readiness for children from low-income families. Journal of Educational Psychology, 102(1), 43.

Zhang, Y., \& Wildemuth, B. M. (2009). Qualitative analysis of content. Applications of social research questions in information and library. Portland, OR: Book News. 